\title{
From Persecution to Management of Populations Governmentality and the Common European Asylum System
}

Elspeth Guild Jean Monnet Professor ad personam, Centre for Migration Law, Radboud University, Netherlands, elspeth.guild@conflits.org

Deploying the three techniques of governmentality which Foucault developed most - sovereignty, discipline and biopolitics, this article dissects the asylum protection system which the EU is developing and makes visible the underlying structure of authority and power. The article considers the development of the Common European Asylum System from the perspective of the underlying tensions regarding the treatment of people and their management.

\section{Introduction}

Refugee protection has long been an issue of great moral and legal importance among the countries in Europe. European states sent representatives to participate in the drafting of the UN Convention relating to the status of refugees 1951 together with its 1967 protocol (the Geneva Convention) ${ }^{1}$ - the international commitment to refugee protection and were among the first signatories. They have also been strong supporters of the UN Agency established as guardian of the Geneva Convention - the United Nations High Commission for Refugees (UNHCR) and participate as members of the UNHCR's Executive Committee. However, these same states, when adopting legislation on refugee protection in European Union law $(\mathrm{EU})^{2}$ appear Janus faced. On the one hand, statements of commitment to refugee protection are plentiful, on the other, mechanisms are adopted which aim to exclude the refugee even from being heard. In this article I will examine this contradiction using the concept of governmentality as developed by Michel Foucault. Deploying the three techniques of governmentality which Foucault developed most - sovereignty, discipline and biopolitics, I seek to dissect the asylum protection system the EU is developing and make visible the underlying structure of authority and power. While some academics place great emphasis on the development of a risk society, my project is not that. It is an investigation of the articulation between discipline and biopolitics in relation to law.

Before 1999, asylum was an issue for the Member States and the role of the EU was no more than to provide a space within which discussion could take place and political agreement reached. As the numbers of persons seeking protection as refugees in Europe began to rise from about the mid 1980s to the mid 1990s and when the political significance of refugee protection in Western European states as flight from Communism lost its meaning after $1989^{3}$, the enthusiasm of European states to provide refugee protection came under strain. Increasingly, people seeking refugee protection in Europe were stigmatized as 'bogus' and the object of suspicion regarding their motives. ${ }^{4}$ The fact that asylum claims dropped in number by more than half in Europe between 1995 and 2010 is a fact that is rarely mentioned in the debate. ${ }^{5}$

As the image of the deserving refugee became detached from that of the 'bogus' asylum seeker (that is someone who is seeking international protection but in respect of whom the state authorities have yet to make a decision regarding the claim), and the later became the 
object of increasing odium, some European states which are members of the European Union (Member States) began to discuss asylum policy among themselves. These discussions began around 1985 but were only formalized in 1993 in an EU venue. It was not until 1999 that the EU was given powers to develop a Common European Asylum System (CEAS). Elsewhere I have examined how and why refugees became excluded from EU rules on movement of persons which date from $1957 .{ }^{6}$ Instead, refugees were increasingly marginalized into their own separate universe in EU law. The first five year programme for the development of an asylum system, the Tampere Conclusions 1999 called for two phases to the development of a Common European Asylum System (CEAS) - a first five year period within which the adoption of minimum standards would take place and a second moving to one common system. A second multiannual programme in 2004 (The Hague Programme) prodded the institutions to complete the first round of asylum legislation and the third multiannual programme adopted in Stockholm in December 2009 called for the completion of a truly common CEAS. In the meantime the European Commission proposed a series of changes to the existing legislation to achieve a common set of standards in 2009. These proposals are currently under negotiation. After more than ten years of a CEAS, it is time to examine the key characteristics of the system. What has happened to refugee protection under the system - how can we understand the nature of refugee protection in light of the EU's engagement in the field?

The purpose of this paper is to widen our understanding of the mechanisms of governance at work in the CEAS while at the same time avoiding what can be a somewhat simplistic argument about the denial of humanity to asylum seekers in the EU. The latter rather sterile approach not only fails to provide insights into the processes at work and the power structures in transformation but more critically, it is blind to the complexity of sovereignty which is at the centre of the changes. While my approach opens many questions and new avenues of research, nonetheless, it permits a more complete understanding of what is at stake. One is not required to forget a whole series of developments, legal measures, court judgments etc. simply because they do not correspond with the homo sacer ${ }^{7}$ analysis of the EU asylum system which is popular in some critical quarters. What interests me in this paper is how and with what consequences the EU moves into the field of asylum and what structural changes take place either as a result of or in tandem with this shift of power. My objective is not to plot a cause and effect relationship but rather to understand what has happened to refugees over this ten year period.
My contention is that the CEAS is in fact creating a system which not only changes the meaning of sovereignty but which changes the way in which governance takes place in respect of the individual. Much has been written about the move of sovereign powers between the EU institutions and the Member States. ${ }^{8}$ What interests me in this paper, however, is to escape that debate characterized by a rather Aristotelian hierarchy of authority ${ }^{9}$ and instead to look at how the EU measures change the nature of power relations among state authorities and individual asylum seekers. To carry out this examination, Michel Foucault's concept of governmentality is particularly apt. ${ }^{10}$ What are the mechanisms of governmentality which the CEAS enables, blocks or transforms and which regulate the lives of individuals seeking international protection in the EU? It is important to bear in mind that governance and governmentality are not the same thing. I am interested in the governmentality of the governance of the EU. Governance encompasses the formal structures within which authority is exercised. Governmentality, on the other hand, examines the conditions under which authority is constituted and dissipated.

In the critical social sciences beyond law, the work of Michel Foucault has been applied to the question of detention of foreigners and the situation of asylum seekers. ${ }^{11}$ I will not repeat this work some of which I have criticized elsewhere for an inability to take into account the transformation of how power is exercised in Europe. ${ }^{12}$ Here I want to examine the EU's engagement with asylum seekers in order better to understand the mechanism of power and how it operates between the EU and the Member States played out on the lives of asylum seekers and refugees. Foucault suggests three different ways of thinking about power as a relationship among people. ${ }^{13}$ The first is sovereignty. Unlike the usual meaning of sovereignty as relations among states and state structures, Foucault focuses on the sovereign as the individual/entity with the power of life and death over others in a relationship where the sovereign does not need or enter into any other relationship of power with the individual. ${ }^{14}$ Law provides the mechanism to determine life and death according to Foucault. The sovereign form of power, or as Foucault seems to indicate in his later work, governmentality, is that of raison d'état or police state (Polizeistaat) transformed and restructured by discipline and biopolitics when the notion of people and law are placed at the heart of the decision making about death and punishment. ${ }^{15}$

The second form of exercise of power or governmentality ${ }^{16}$ which Foucault uses is that of discipline. Here the individual is differentiated from all other living bodies on which power can be inscribed and which is also the site of resistance. ${ }^{17}$ Power is exercised through the dif- 
ferentiation of the individual through discipline which is the flipside of individualization. Through mechanisms of discipline: prisons, schools, insane asylums etc, individuals are conducted ${ }^{18}$ towards conformity to a set of rules. The modalities of discipline include self discipline and responsibility. Discipline is thus a productive form of power according to Foucault's approach. ${ }^{19}$ The three are techniques which generate obedience and resistance which are necessary to forms of authority which are more complex. ${ }^{20}$

The third form is biopolitics which depends centrally on the creation of knowledge through the categorization of life. ${ }^{21}$ The collection of statistics about beings creates the possibility to allocate attributes such as normal/abnormal, human/animal etc to groups and individuals as they are tested against a norm created through the amassing of information. Instead of the body relationship of discipline, power is transmitted through the creation of norms and their relationship with risk. Life is managed through the establishment of norms based on the collection of amounts of information and their synthesis into common characteristics which can then be applied to the individual. ${ }^{22}$ Foucault distinguishes between normalization which is the result of statistically determined averages and normation which is the way we determine what is 'normal' as opposed to 'abnormal'. ${ }^{23}$

None of the three forms operates in a vacuum. Aspects of all three different modalities of the exercise of power may be in operation at the same time. Altogether they constitute the means of governmentality - the way in which authority is constructed and deployed. Foucault's world is populated by apparent contradictions and overlaps among the ways in which power relations are constructed and managed. Law as a form of governance works equally satisfactorily in all three different modes (sovereignty, discipline and biopolitics) through the attributes of rule of law which include human rights norms. ${ }^{24}$ An important aspect of Foucault's reasoning is the distinction between the pastoral form of power where the analogy of the shepherd and the flock is used. The shepherd has a duty to find the lost lamb even if this places at risk the flock. This pastoral power is contrasted to utilitarian and predatorial exercise of power where in the name of the good of the people anyone or any group can be sacrificed. ${ }^{25}$ The originality of Foucault's approach is not least in its ability to escape from what was becoming an increasingly sterile debate among political philosophers about the nature of the state and state relations. ${ }^{26}$ By moving to the practices of power, Foucault opens a whole series of new perspectives on how power works. However, Foucault takes as a given the relationship of the sovereign to space - the sovereign exercises power over a space within which he/it has control and the last word. Whether this is in the form of the right to kill or not (the first form), to determine transgression and decide on punishment (the second form) or to choose which categories of information will be collected and what meaning they will have vis-à-vis the management of life (the third form), they do not permit a further layer of interaction and mediation between the sovereign and the supra-national where the last word is the outcome of other mechanisms of power relations.

To take a simple example from the EU, there is currently a raging discussion about the treatment of Afghan and Iraqis asylum seekers in different Member States of the EU. UNHCR has criticised heavily the CEAS because outcomes for Iraqis are so inconsistent among Member States (for Afghans this means a 0 recognition rate in Greece and 75 per cent in Finland in 2009). ${ }^{27}$ The European Commission has responded to these criticisms indicating that the CEAS is still under construction and as the system begins to work better these differences should disappear. ${ }^{28}$ The result is that in a Foucauldian analysis, the national administrators who are applying the CEAS become the people at the cutting edge of being disciplined in this scenario of supra-national. They are the ones who must do better to render the system coherent (ie reduce differences among recognition rates for asylum seekers from the same countries) rather than respond to the indications given by their national administrations (ie sovereigns) on how countries of origin (or applications) should be assessed.

I will look at two different aspects of the CEAS from the overlapping power mechanisms of Foucault:

1. How are asylum seekers rendered visible and invisible as rights holders through EU law; here the key is the Procedures Directive ${ }^{29}$ which describes which asylum applications must be determined and which can excluded - some asylum seekers cease to be an undifferentiated part of a flow of persons and become individuals with rights and complaints and a story to tell. Others remain part of a group subject to life and death decisions but not individualization. Mechanism after mechanism is described which permits the administrator to avoid listening to the story of the asylum seeker. Safe country of origin, safe third country, presumptions of manifestly unfounded applications, assessments of countries of origin - all these mechanisms are designed to release the national administrator from the duty to treat the individual as an individual. Instead, the individual becomes part of a category about which a variety of information is collected and then applied to prevent the individual 
to differentiate him or herself from the category. This differentiation of the asylum seeker into an individual corresponds best to Foucault's second category of discipline. The individual must fulfill the criteria to be a refugee or suffer the fate of the rejected asylum seeker - expulsion.

2. How does the CEAS operate as a system of biopolitics - the management of life through statistics and assessment of risk. This is the most murky of Foucault's categories which he developed least in his work but which has been the subject of substantial discussion and analysis since.

\section{The right to seek asylum - the right to have a claim determined}

Foucault's notion of governmentality rests on three connected mechanisms. First there is the mechanism of discipline - the construction of authority through the establishment of rules and hence of a claim to discipline and punish the offender - an act carried out inter alia on the body. ${ }^{30}$ Foucault uses Bentham's panopticon to exemplify this mechanism of governmentality. The authority in a prison is expressed through the possibility of the guards in the guardhouse at any time to see any prisoner. The structure of Bentham's prison permits the guard to look into the cell and see the prisoner and thus to know at any given moment whether the prisoner is obeying the rules. The capacity to punish is enhanced through the capacity to keep the individual under surveillance. While the guards may not watch each prisoner all the time, the prisoner does not know when he or she is under surveillance and when he or she is not. This results in asymmetry of knowledge which brings a differential in the power relation. The prisoners cannot see the guards so have no knowledge of their actions which conform to or break the rules but the opposite is true. Indeed, this is an example of power operating by itself - not as something possessed by individuals. ${ }^{31}$

Two aspects are important, first, the guards are able to exercise much greater control as they are able to see prisoners whenever they wish to ensure that the rules are observed and are able to punish more quickly offenders. Secondly, the prisoner who knows that there is this capacity of surveillance knows that punishment for offending against the rules does not depend on the prisoner being aware of whether the guards are watching or not. In order to avoid punishment the prisoners are drawn to exercise auto-discipline - they do not undertake acts against the rules as they fear punishment. ${ }^{32}$ The third step for Foucault in the explanation of how governmentality works is responsibility. The authorities acknowledge the freedom of the individual to act but warn the individual of the consequences of any particular act. ${ }^{33}$ The example which Löwenheim provides is that of foreign ministries in liberal democracies which publish warnings to their citizens regarding various countries, advising them not to go to those countries because of a variety of risks, spelt out in the notifications. ${ }^{34}$ On the one hand, the authority reinforces the individual's perception of freedom by accepting that the individual can travel to any country he or she wishes to visit. On the other hand, the authorities create a responsibility on the individual related to risk, danger and bodily harm (which finally, according to some of the steps Foucault takes towards biopolitics, the individual has learned is the greatest ill to be avoided) - if the individual insists on going to a dangerous country he or she takes the risk of the consequences. This then has important consequences for the state's responsibility of protection for its citizens abroad.

So discipline, as the political technology of the body, includes directly disciplining individuals, auto-discipline and responsibility. A Dean points out »Foucault himself puts this argument for the interdependence of citizenship rights and disciplinary power in an more general form: the 'Enlightenment' which discovered the liberties, also invented the disciplines. " $^{35}$ The question now is how does this approach provide clarity to the CEAS - does Foucault illuminate the structure of the CEAS and the construction of authority in respect of the asylum seeker?

The surveillance of the EU external border by the Member States and coordinated by FRONTEX ${ }^{36}$, echoes Foucault's use of Bentham's panopticon but only in part. As Bigo has developed, ${ }^{37}$ the EU external border is more of a banopticon, invisible or very light for the so-called bona fide traveller but a block to the asylum seeker and the person suspected of seeking to enter the EU irregularly. Among the fundamental problems of this approach in the EU is determining who is likely to be an irregular migrant, who an asylum seeker and who is a bona fide traveller (thereby creating these population categories). People coming from the same countries may fall into all three categories.

Contrary to the idea of clear cut categories (such as Weberian ideal types) those of sovereignty, discipline and biopolitics are intertwined in time. The suggestion that each age is dominated by one category only would entail the disappearance of sovereignty, law and discipline in a risk management society governed by biopolitics only. This is obviously not the case. It is important to show that discipline is embedded into biopolitics of population and reframed in order to supplement this biopolitics. The EU, however, has taken a risk-oriented approach - if there is a risk of irregular migration then further exclusionary procedures apply (visa requirements, in depth interviews 
at consulates abroad before travel, immigration liaison officers at some airports to provide advice to airlines whom to refuse boarding access, reinforced border patrols at land and sea borders etc). The creation of the category of foreigner who is risky, who should be under surveillance is established. The group is based on heterogeneous characteristics - completely different countries of nationality, different social and economic classes (though the poor are generally a risk), different genders. The measures are adopted to keep under surveillance and outside the EU this collection of people who are transformed into a population though they share no common characteristics outside those which are allocated to them by the EU border surveillance system. ${ }^{38}$

Having established the subject population, (which does not, for instance include US nationals who do not require visas, in respect of whom no immigration liaison officers are posted at US airports, who are assumed not to be poor) the next step is to establish surveillance. The illusion is of a panopticon, the EU immigration guards can see every EU external border simultaneously though they may not be looking at any given moment. But it is actually more of a banopticon where the majority of travellers are unaware of those under surveillance and do not consider themselves to be so. Where individuals are perceived to be irregularly crossing or seeking to cross a border then they are the subject of discipline. The EU's external border surveillance system, EUROSUR is designed to do exactly this. ${ }^{39}$ The proposal sets out a roadmap for setting up a 'system of systems' interconnecting and rationalising border surveillance systems at the national level, improving the performance of surveillance as a tool and creating a common monitoring and information-sharing environment for the EU maritime domain. The objective is to focus on the EU's southern and eastern maritime borders and achieve full awareness for border guards of the situation at the external borders.

If the (wrong) individuals manage to cross the border into the EU then they may be denied entry and should be expelled. ${ }^{40}$ If they are perceived to be trying to arrive at the EU external border, FRONTEX operations aim to prevent their arrival and to send them back whence they came. If they are obstinate and continue, they are at high risk of drowning in the Atlantic on route to the Canary Islands, in the Mediterranean on route to the Italian, Maltese, Greek or Spanish coasts. ${ }^{41}$ Alternatively, they may be killed by the border guards of neighbouring states outside the EU (which are major beneficiaries of EU border surveillance funds) such as Libya, Tunisia or elsewhere. ${ }^{42}$ Thus there is the establishment of authority through a system of surveillance and punishment of a population designated by the authority itself in accord- ance with rules it has unilaterally determined. What is new in this constellation is the way in which it is cut free from the state. Instead of Member State actions, these are European initiatives and measures, an EU agency which is at the centre of the project of surveillance and punishment. The punishment is presented as a form of risk rather than direct punishment. FRONTEX officials and state border guards consistently deny that they are in any way complicit in the drowning of persons in the Atlantic or Mediterranean or the killing of individuals by border guards in third countries when those individuals are seeking to leave those third countries to enter the EU. ${ }^{43}$ Nonetheless, the numbers of persons who lose their lives in this way raises serious questions. If the EU agency is so successful at surveillance of the external border surely it is capable of ensuring that people do not die there ${ }^{34}$

Assuming that the population is a homogeneous one, as the EU seeks to do, then the fact of punishment through death, detention and expulsion ought to create self-discipline of each individual coming within the group of people on the move, not only the one who has been the subject of the measure. The deterrence effect should result in the 'conduct of the conduct' in other words the capacity to structure the choices of others. ${ }^{45}$ The individuals should learn not to behave in this way - ie to try to gain access to the EU as this will create a high risk of death, detention or expulsion. The problem is that this is not a homogeneous population. ${ }^{46}$ People who move are a highly diverse group who travel for such a wide variety of reasons that it is virtually impossible to classify them all. The third of Foucault's mechanisms of governmentality - responsibility - is embedded in the second, auto-discipline in the case of EU approaches to irregular migration. The pervasive argument is that these persons ought to know that they are putting themselves at risk. If they do not know, then this is the fault of another image which has taken shape in the hands of the EU - the trafficker and smuggler of human beings. This is the evil exploiter of human misery who hides the risk from the irregular migrant and charges high fees for doing so. ${ }^{47}$ However, the intermediary between the authority and the offender is only a secondary target, the main target is the foreigner.

The asylum seeker creates a series of tensions within the system by belonging to a class entitled to international protection. At great cost to logical argument, even common sense, the EU and the Member States resist strenuously all suggestions that the right to protection to which the refugee is entitled from them in international law includes a right to arrive at the border of the territory. ${ }^{48}$ Instead the EU and the Member States cling relentlessly to the idea that only the lucky or devious refugee who has 
managed to escape all the obstacles (legitimate, according to the EU and its Member States) which have been placed to prevent him or her from ever getting near an EU border, and has arrived in the state is entitled to protection (if, of course, he or she can present an argument which the state accepts as entitling him or her to protection). UNHCR continues to argue that the foreigner who claims asylum from the authorities of a state is entitled to a consideration of that claim. This is the principle contained in the Dublin II Regulation and the Qualification Directive. Thus the foreigner is part of a population which is being actively persuaded (by a FRONTEX operation for instance) not to enter the territorial waters of an EU Member State, nonetheless if the individual is seeking international protection he or she should be entitled to the benefits of the Qualification and Procedures Directives. This is a very inconvenient position for the EU border surveillance system. If accepted, it cuts a huge hole in the centre of the design - the population which has been constructed as the object of the governmentality project cannot be treated as a single population because of the socalled mixed flows problem (ie flows of both potentially irregular migrants and refugees together).

When the individual arrives in the EU, as so many still do notwithstanding, ${ }^{49}$ he or she faces a series of disciplining measures in the search for protection. Asylum seekers start as individuals, foreigners who arrive at the border of a territory. If they have not read the Geneva Convention and the EU Procedures Directive (a common failing among them as a group) they do not know that they are obliged to seek asylum from an official as soon as they arrive at the territory. But if they delay in making their asylum application they may not obtain a full procedure. Article 23(4)(i) and (j) Procedures Directive states that Member States may prioiritise or accelerate (which means a truncated procedure) any application which is considered unfounded because "the applicant has failed without reasonable cause to make his/her application earlier, having had the opportunity to do so or the applicant is making an application merely in order to delay or frustrate the enforcement of an earlier or imminent decision which would result in his/her removal." The state authorities decide whether an individual comes within one of these categories. However, if the asylum seeker has read the Procedures Directive he or she might baulk at making an application for asylum at the border after reading Article 35 which permits Member States to maintain border procedures which do not fulfil the procedural requirements of 'normal' applications, in particular they may be denied a judicial remedy.

Once asylum seekers are on the territory and have made an asylum application they are within the EURO-
DAC system and so under surveillance in a very obvious way. But just to make sure that the asylum seeker does not seek to hide his or her 'true' identity, article 23(4)(d) Procedures Directive allows Member States to truncate the investigation of the claim to international protection because "the applicant has misled the authorities by presenting false information or documents or by withholding relevant information or documents with respect to his/her identity and/or nationality that could have had a negative impact on the [protection] decision«. State authorities will not tolerate complex identities. Asylum seekers are not like other people, they are obliged to inform the state about all aspects of their existence. Article 11(2) Procedures Directive sets out among the obligations on the asylum seeker to the state:

- A requirement to report to the competent authorities or to appear before them in person either without delay or at a specified time (specified by the state authorities);

- A requirement to hand over to the authorities documents in their possession relevant to the examination of the application, such as passports;

- A requirement to inform the competent authorities of their current place of residence or address and of any changes thereof as soon as possible. Member States may provide that the applicant shall have to accept any communication at the most recent place of residence or address which he/she indicated;

- A requirement to submit to searches by the competent authorities both of the person and of any items which the asylum seeker has with him/her;

- A requirement to submit to photographs;

- A requirement to submit to recording of oral statements (though the authorities must advise the asylum seeker that a recording is being made).

Asylum seekers are defined out of rights such as that of integrity of the person. The state has claimed the right to carry out searches on asylum seekers bodies and property without the obligation to justify why or to have reasons for such searches. However, this EU framed exclusionary move is always countered by the supranational legal framework which at the same time prohibits it. ${ }^{50}$ The struggle is one between the capture of individuals into a population as a category and the supranational human rights legal system which entitles the individual to escape.

In order to move from being asylum seekers to refugees, individuals need to engage with the Member States' administrations and to persuade them of the validity of their claims. While individuals have lives and stories full of contradictions, incoherence and detail, the claim to 
international protection must be accompanied by a single coherent, consistent story without deviations or messy edges which proves that the individual fulfils the definition of a refugee - a well-founded fear of persecution on the basis of race, religion, nationality, membership of a particular social group or political opinion. The punishment for failing to present a clear, consistent and coherent story comes in a number of forms. First, a messy claim will not get a full procedure. Article 23(4)(g) Procedures Directive states that a Member State can prioritize or accelerate (ie limit procedural rights) where »the applicant has made inconsistent, contradictory, improbable or insufficient representations which make his/her claim clearly unconvincing in relation to his/her having been the object of persecution..." This will assist towards the claim being rejected outright. In this case the individual will probably become a person irregularly present on the territory and subject to detention and expulsion. Alternatively, the state authorities may decide that although the refugee claim is not made out the individual needs international protection and so under the Qualification Directive is entitled to subsidiary protection.

In the second case the punishment is immediately evident - reduced procedural guarantees for the asylum claim. In the first the punishment is no protection, the threat of detention and the menace of expulsion. These punishments are normally accompanied by notification that the individual is illegally present (ie use of the criminal law directly), ${ }^{51}$ a prohibition on working and the denial of all social benefits and housing. Once refused asylum, the individual can no longer claim material support under the Reception Conditions Directive. The individual is thus further punished by destitution. In the second case, the punishment is more subtle. While the individual gets a status, those who are given subsidiary protection rather than refugee status have many fewer entitlements. They may be granted lower social benefits and limited health care. They get reduced access to family reunification. Articles 9-12 of the Family Reunification Directive $2003 / 86^{52}$ provide for family reunion for refugees under conditions which are more favourable than those applying to other third country nationals. However, Article 3(c) excludes from its scope persons with subsidiary protection. Thus access to family reunification for anyone with a status less than full refugee is left to the vagaries of national law. Persons with subsidiary protection have residence documents of shorter duration than those which must be accorded to refugees. They are punished for their failure to provide a sufficiently coherent story by being allocated a less favourable residence status. ${ }^{53}$ However, in most Member States the majority of persons who are given subsidiary protection come from the same countries as those who receive refugee status. According to UNHCR 2008 statistics in the Netherlands 91 Iranians were recognised as refugees and 138 were given subsidiary protection. In the UK 290 Iranians were recognised as refugees and 170 got subsidiary protection. In Sweden 124 were recognised and 51 got subsidiary protection. In Denmark the figures were 118 refugees and 12 beneficiaries of subsidiary protection.

Once again, the asylum seeker ought to know that he or she is required to provide a clear and consistent statement. Indeed, in many Member States information pamphlets are given to asylum seekers warning them of the necessity to provide a clear and concise statement which corresponds to the refugee definition in the Qualification Directive. Thus states seek to make the individual responsible for his or her fate. If the individual persists in being unable to provide such a clear and coherent statement then the risk of a lower status or refusal is on him or her.

Further, the asylum seeker is also made responsible for the acts of third states through a transmission of duties of third countries onto the figure of the asylum seeker. For instance, if the asylum seeker is trying to enter the state or has entered the state 'illegally' from a country which ought to be safe, then the Member State where the application is made has no obligation to examine the application at all. There can be no procedure at all within which the asylum seeker can make his or her claim for international protection (Article 36 Procedures Directive). The directive then goes on to set out how these countries which ought to be safe are to be determined European safe third countries as they are designated. The characteristics of the European safe third country which have the consequence of denying the asylum seeker an opportunity to have his or her claim to protection heard in an EU Member State are:

- The country has ratified and observes the Geneva Convention;

- It has in place an asylum procedure proscribed by law;

- It has ratified the European Convention on Human Rights and observes its provisions including standards relating to effective remedies;

- It has been designated by the Council as a safe third country. ${ }^{54}$

In 2009, according to UNHCR statistics, Russian nationals were the third largest group of persons seeking asylum in the EU (after Iraqis and Somalis). ${ }^{55} \mathrm{~A}$ case can be made that the Russian Federation fulfils three of the four criteria to be a European safe third country: it has ratified and observes the Geneva Convention; it has an asylum procedure in place; it is a party to the ECHR 
and appears regularly before the Court but as there is no designated list of safe third countries by the Council (yet) this final criterion is missing. If one examines UNHCR statistics for $2008,{ }^{56}$ protection rates in EU countries for asylum seekers from the Russian Federation was running at 17 per cent in the Netherlands, 53 per cent in Poland and 70 in Denmark and Finland. Average protection rates in the EU tend to vary around 10-30 per cent.

State authorities' capacity to punish the asylum seeker and the practices of punishment are not always co-extensive. However, the key point here is that it is the asylum seeker who, by reason of having travelled through the Russian Federation and having arrived at the border of an EU state or entered 'illegally', is made responsible for the Russian Federation's treatment of asylum seekers. Subject to the adoption of a list of safe countries of origin by the Council (which is currently blocked) he or she could be returned to the Russian Federation without any examination of his or her asylum claim in the EU as the Russian Federation can be classified, according to the EU's criteria as a safe third country. The fact that Russia is an important country of origin of refugees and beneficiaries of subsidiary protection in the EU does not affect the EU's capacity to classify that state as safe for asylum seekers from other countries. The asylum seeker's alleged choice of travelling through Russia to get to the EU results in the asylum seeker bearing the consequences of the EU's assumption that the Russian Federation is a safe place for the asylum seeker to seek protection. If the asylum seeker does not want to be sent to the Russian Federation to seek international protection he or she should not travel through it on his or her way to the EU! ${ }^{57}$

The Procedures Directive adds a number of finesses to the discipline, auto-discipline and responsibility of asylum seekers. The directive includes punishments in the form of procedural presumptions against the individual which apply in various circumstances. As outlined above, these apply to the individual who failed to apply for asylum immediately or as soon as possible after arrival in the territory of a Member State may be punished by being given few procedural guarantees. Similarly, the individual who has trouble providing a story which fulfils the strict legal definition of a refugee is punished by a presumption that his or her claim is manifestly illfounded because the state authorities consider that it is not plausible or there are internal inconsistencies. These procedural punishments lead towards rejection of the protection claim - the greatest punishment for failing to persuade the authorities of the need for international protection. Similarly, a careless, unwitting or unavoidable travel choice may result in the asylum seeker getting no consideration of his or her protection claim in the EU.
To give the system of punishments against the asylum seeker greater coherence and impact, many Member States have increased the expulsion of persons to whom they have refused asylum. These persons are designated as 'failed asylum seekers'. The use of the term 'failed' evokes fault of the individual that he or she has not succeeded in obtaining international protection just as students who fail their exams did not study sufficiently or were inadequate. The individual is responsible for his or her fate, the authorities warned him or her of the risk of a poor application but he or she persisted in pursuing, inadequately, the claim. ${ }^{58}$ Foucault's template for analysis of governmentality through discipline provides a most revealing picture of the CEAS.

\section{The CEAS as an instrument of Biopolitics?}

In this final section, I will examine the most complex of Foucault's categories - that of biopolitics - and how it assists us to understand the system of governmentality which is at work in the CEAS. In his own work, Foucault opened a number of windows of research regarding biopolitics which lead in rather different directions. He was less than clear about what the term means. ${ }^{59}$ The separation of life into zôe - the force of life itself not limited to humans, and bios - life as lived by humans alone has been developed by Agamben ${ }^{60}$ in particular in relation to foreigners and detention centres. His contention is that in Europe there is a trend to deny the bios of the foreigner. Butler $^{61}$ follows quite a different approach to biopolitics which Foucault opened, that relating to the learned and thus ultimately political nature of even those responses which we considered to be our most intimate. Butler develops, in particular, Foucault's interest in the example of gender and sex.

For the purposes of this section, I will focus on another aspect of Foucault's concept of biopolitics which is that related to the management of life itself. ${ }^{62}$ How does the CEAS reduce the individual to a population which is managed, not least through statistical information which is then applied to the individual and has the consequence of preventing the individual from escaping through his or her claim to differentiation? At the heart of the CEAS is the endless search for the mechanism to differentiate the deserving asylum seeker from the one who must become the failed asylum seeker. A quicker, surer system for reaching decisions on individual cases is the holy grail - in particular a system which does not require too much expenditure of state resources in personnel, training etc. Indeed, if there is a safe way to decide cases which is collective and thus avoids the need for officials to spend time looking at individual stories and trying to decide whether they are true or false, this is what many 
Member States would like most of all from the CEAS. On the other hand, UNHCR endlessly reminds the Member States and the EU institutions of their duty under the Geneva Convention to consider each asylum claim and to make sure that no one who has sought international protection is rejected if the consequence would be that he or she would be sent back to persecution. ${ }^{63}$ The problem is how to reconcile these two objectives, satisfy UNHCR and fulfill the states' obligations in international law and decide cases rapidly and with a minimum expenditure of resources.

The Procedures Directive provides a tool in the form of a number of concepts which allow state authorities to divide individuals into groups and deal with them collectively, rather than as individuals. These are:

- The European safe third country (discussed above);

- The first country of asylum;

- the [general] safe third country and

- the safe country of origin.

The key is to create a category according to a set of rules which are not subject to change by the individual then to ensure that the individual classified as belonging to the category has little or no chance of escaping it. The justification for the class is based on statistical information used to construct the group. The individual once classified as belonging to it, is not allowed to differentiate him or herself from it. I have described the European safe third country principle above. In this case, Member States can simply dispense with a procedure altogether where the asylum seeker has passed through a European safe third country en route to the Member State. These people simply do not exist for the Member State as a category in respect of which the authorities are obliged to consider a protection claim at all, the individual is fully and successfully subsumed into a group which does not enjoy a right to protection in the Member State under the Geneva Convention (Article 36 Procedures Directive).

Similarly, the first country of asylum concept creates a category of persons in respect of whom any application for asylum can be dismissed without consideration as inadmissible (Article 25 Procedures Directive). Like the European safe third country concept, the category is constructed not in relation to the individual characteristics of the asylum seeker and his or her claim but by virtue of the state authorities' assessment of a third country (ie not the country from which the asylum seekers fears persecution). This class of persons contains every asylum seeker who can be sent to a country which fulfils, in the opinion of the decision maker, one of two characteristics (Article 26 Procedures Directive):
- The country has recognized the asylum seeker as a refugee (and that status is still available to the individual; or

- The country will make available to the individual sufficient protection including protection from refoulement.

The unifying feature of the two branches of the concept is that state officials are entitled to believe and rely upon assurances from other countries regarding what their officials will or will not do in respect of the asylum seeker and thereby avoid considering the claim of the asylum seeker him or herself. There is no obligation on Member States even to listen to an account of the individual's claim regarding persecution so long as the authorities of another state confirm that they will permit the individual back into their state and not refoule him or her to a state where there is a real risk that he or she will suffer persecution.

The [general] safe third country concept creates yet another category of asylum seekers, sui generis among themselves, as the only characteristic which they share is the way in which they have been designated by the Member State where they seek asylum as persons whose claims are inadmissible. The consequence of being designated as an asylum seeker with a safe third country option is that the protection claim can, once again, be treated as inadmissible (Article 25(2)(c) Procedures Directive). As above in respect of first safe country of asylum, this means that the state authorities are not required even to receive, let alone read or struggle with, the account of the individual's persecution. The elements of the safe third country concept, like those of the safe first country concept, depend on the confidence of the state authorities regarding the practices of another state's authorities. The individual has no control over that assessment as it has nothing to do with the individual characteristics of the asylum seeker. It becomes a matter between states. The Member State where the asylum seeker has sought protection can consider the application inadmissible if there is another state which fulfils the following characteristics, according to the Member State officials' assessment: ${ }^{64}$

- The state will not threaten the life or liberty of the asylum seeker on account of his or her race, religion, nationality, membership of a particular social group or political opinion;

- The state will not refoule the individual to a country where there is a substantial risk he or she will suffer persecution;

- The state will not send the individual to a country where there is a substantial risk that he or she will suffer torture, inhuman or degrading treatment; 
- The state's legal or administrative system allows for the possibility that the individual can make an application for asylum and if the state authorities determine the application favorably they will provide protection to the individual.

Instead of the individual's claim of persecution being the subject of carefully scrutiny, it is the assessment by the Member State authorities of the adequacy of the third country's asylum system which becomes the focus of attention. Article 27(2) Procedures Directive requires the state authorities to have national legislation for the safe third country concept. The rules must include some connection between the asylum seeker and the third country which makes it reasonable to send the person there though there is no need for the individual ever to have set foot in the third country and there are no examples provided of what kind of connection might be adequate. The matter is left to the imagination of the Member State authorities and their legislators. The methodology by which the Member State authorities determine safe third countries must fulfill one of two requirements: either it includes a case by case consideration of the safety of the country for the particular asylum seeker or it includes a national designation of countries considered to be generally safe. In the first limb of the provision there is a vestigal and displaced asylum determination procedure which instead of considering whether the asylum seeker would be persecuted by the state which he or she claims intends to persecute him or her, it requires an examination whether the individual will be persecuted by quite another state with which the individual may have only the most tenuous ties (Article 27)(2)(b) Procedures Directive). The second limb removes the asylum seeker from the equation - the only relevant consideration is whether some state through which the individual passed on his or her way to the EU state has been designated by the national authorities as safe.

Nonetheless, the Member State must have rules which allow the asylum seeker to challenge the safe third country allocation on the basis that he or she would be subject to torture, inhuman or degrading treatment in that country (Article 27(2)(c) Procedures Directive). One has a sense that here, at least, the individual can escape the oppression of the category into which he or she has been pushed. However, on examination, one sees that in fact, this escape valve is the direct and unavoidable application of Article 3 ECHR. Council of Europe states, whether they are EU Member States or not, are under a general duty not to return someone to a country where there is a substantial risk that he or she would suffer torture, inhuman or degrading treatment or punishment. The ECtHR has held that this obligation must be carried out on the basis of an individual consideration of the circumstances of each person. ${ }^{65}$ Effectively, what the Procedures Directive does here is acknowledge that it is subservient to international rule of law at least as regards the European Convention on Human Rights. As the ECHR has its own court which interprets the meaning of the ECHR, the EU is obliged to acknowledge the primacy of that interpretation of the ECHR rights, rather than one which some Member States might prefer. Indeed, Article 6 Treaty on European Union (TEU) acknowledges the duty of the EU (including its Member States when within the scope of EU law) to respect the ECHR. Further it calls for the $\mathrm{EU}$ to accede to the ECHR.

This is the most important difference between the way in which the ECHR operates as a restraint on the EU legislator through its independent judicial supervisory body and the way the Geneva Convention operates. In respect of the latter the EU legislator can and does make endless references to the supremacy of the Geneva Convention and its obedience to international rule of law and then goes on the interpret the Geneva Convention as it wishes whether or not that coincides with the interpretation which the Member States themselves agreed in the context of the UNHCR Executive Committee. ${ }^{66}$ The TEU now also calls for the EU to accede to the Geneva Convention.

The final concept which I will consider here is that of safe country of origin. This is a category which designates the individual by reference to his or her country of origin. It is the classification of people as not refugees because they are nationals of a specific state. As such it is the most controversial as it denies the very essence of the refugee, the individual who claims a well founded fear of persecution from his or her country of origin. The concept is one which obliterates Geneva Convention protection on the basis of where an individual comes from. It is inherently contradictory to the Geneva Convention as it undermines the universality of the right to protection. Instead of all people being eligible for protection from persecution only people from some countries are, not those from other states. For this reason the category of asylum seekers who can be denied a consideration of their claims on this ground is more fluid than the other categories. While it is very hard if not impossible for an asylum seeker to escape the straightjacket of his or her classification as part of the category of inadmissible applicants under the European safe third country concept, the safe first country of asylum concept or the [general] safe third country concept, there is more wiggle room for those classified as having a safe country of origin which excludes their application. 
As in respect of the category of European safe third countries, the construction of the group requires a decision by the Council. For the same reasons as in respect of the European safe third country category, this list has never been established. The CJEU found in favour of the European Parliament in its challenge to the legality of the procedure for the adoption of such a list. In the Commission's proposal for a Recast of the Procedures Directive it recommends that there be no common list of safe countries of origin only common objective criteria for national designations of third countries as safe countries of origin. In other words, variations among the Member States regarding which countries are safe countries of origin will be permitted but each Member State must justify its list. ${ }^{67}$ The logic of the provision means that where an individual comes from a country which has been designated a safe country of origin his or her application can be considered as unfounded (Article 23(4) (c)(i) Procedures Directive). Article 28 of the Directive requires that the individual must not be a refugee in accordance with the Qualification Directive but the same provision allows Member States to treat the application as manifestly unfounded under national law. So while under the directive the Member State authorities are not permitted to avoid a consideration of refugee status, they are allowed to apply national law to treat the application as manifestly unfounded. This is not only contradictory but smacks of dubious good faith. The criteria for designating a country safe are contained in Annex II of the Directive and include:

- There is generally and consistently no persecution or torture, inhuman or degrading treatment;

- There is no threat by reason of indiscriminate violence in situations of international or internal armed conflict.

Account must be taken of the extent to which protection is provided against persecution or mistreatment. This categorization is generalized and specific to the country. The individual has no chance of influencing the categorization except indirectly by challenging the generality of the categorization.

The search for the collective designation of the individual in order to avoid the consideration of the individual application which is apparent in the CEAS corresponds to one of the meanings of biopolitics which Foucault suggested. The state's control over life and death, as asylum is a matter of life or death, is incorporated into a statistically or collectively based approach to the management of population. The management of risk takes place through the sealing of the individual into a category which is determined according to a collective assessment of the seriousness of the risk. Every effort is made to ensure that the individual does not escape that category as every exception is costly in terms of state resources. The cost of life or death for the individual is subsumed into the state's collective risk assessment strategy which is privileged. The EU becomes an instrument through which there is a generalization of the mechanism of population management through risk assessment. This fulfils two important objectives: it provides inter-state solidarity for the system against complaints by UNHCR, other international organizations, non-governmental organizations and others that the system is inconsistent with the Member States' obligations under the Geneva Convention; secondly, it provides reinforcement against internal dissent within EU states against the application of mechanisms of biopolitics against the most vulnerable individuals in the community - asylum seekers.

\section{Conclusions}

In this article I have examined the techniques of governmentality which Foucault develops - sovereignty, discipline and biopolitics in the context of the EU's Common European Asylum System. Using Foucault's framework to understand the logic of power and authority, the underpinnings of the CEAS become visible. I examine the management of the EU's external border and the categorization of asylum seekers by reference to the external border through discipline as a technology of governmentality. The existence of refugees as a group of persons entitled to cross borders to seek international protection fits uneasily with the EU's development of a common external border control designed to admit and exclude third country nationals on the basis of criteria incompatible with refugee protection. The logic of discipline, autodiscipline and responsibilization of the asylum seeker provides a way to escape the conundrum. If the drowning of the individual in the Mediterranean is the fault of the asylum seeker him or herself for engaging in risk behaviour against the discipline of the EU, criticism is deflected from the EU institutions. Instead, it is the asylum seeker who is failing to respond properly to the discipline and punishment of governmentality.

In the final section I turn to biopolitics as a means of governmentality in the CEAS. The management of life itself (to adopt Rose's terminology) through the creation of categories supported by statistics becomes a particularly powerful tool in the CEAS. The creation of categories of asylum seekers whose claims to protection never need to be heard because they belong to groups excluded from consideration is a cornerstone of the CEAS. The categories are defined on the basis of the Member States assess- 
ment of third countries and countries of origin. The asylum seeker is excluded from influencing the assessment in any substantive manner. The life of the individual asylum seeker is managed through the State's categorization of his or her state of origin or some state through which he or she passed on route, supported by statistics about the incidence of human rights violations there. The individual's capacity to escape the category and to be entitled to differentiation is denied or impaired irreparably. The individual is subsumed, possibly fatally, into a category deemed safe for expulsion.

The CEAS reveals the three techniques of governmentality at work simultaneously. The analytical framework of governmentality indicates some deep flaws in the CEAS as a system which claims to provide international protection to those who need it.

\section{Bibliography}

Agamben, G 1998 Homo Sacer; Sovereign Power and Bare Life Stanford University Press, Stanford.

Bigo, D 2008 'Security: A Field Left Fallow' in M. Dillon and A. Neal Foucault on Politics, Security and War Palgrave, Hounsmills pp 93114.

Bigo, D 2005 'The Birth of Ban-opticon : Detention of Foreigners in (il)liberal Regimes' Paper presented at the annual meeting of the International Studies Association, Hilton Hawaiian Village, Honolulu, Hawaii.

Burchell G 1996 'Liberal Government and Techniques of the Self' in A Barry, T Osborne and N Rose Foucault and Political Reason, Liberalism, Neo-Liberalism and Rationalities of Government University of Chicago Press, Chicago.

Butler J 1999 Gender Trouble Feminism and the Subversion of Identity Routledge, New York.

Caporaso, J 1998 'Integration Theory, Past and Future' in W Sandholtz and A Stone Sweet, European Integration and Supranational Governance OUP, Oxford.

Dean, M 1994 Critical and Effective Histories: Foucault's Methods and Historical Sociology Routledge, New York.

Dean, M 2009 Governmentality. 2nd Edn, Sage, London.

Dillon M \& A. Neal 2008 Foucault on Politics, Security and War Palgrave, Hounsmills.

Foucault, M 1977 (translation: 1977 A. Sheridan) Discipline and Punish: the birth of the prison Penguin Books, London.

Foucault, M 2003 (translation D. Macey 2003); Society must be defended: Lectures at the College de France 1975-76 Palgrave, New York.

Foucault, 2008 (translation G. Burchell 2008) The Birth of Biopolitics: Lectures at the College de France 1978-1979 Palgrave, New York.

Foucault, M 1988 'The political technology of individuals' in L H Martin, H Gutman and P H Hutton (eds) Technologies of the Self: $A$ Seminar with Michel Foucault Tavistock, London.

Gros F 2006 États de violence: Essai sur la fin de la guerre Gallimard, Paris.

Guild, E 2006 'The Europeanisation of Europe's Asylum Policy' Int J Refugee Law Vol 18 No 3-4 pp 630-651.

Guild E 2003 'Exceptionalism and Transnationalism: UK Judicial Control of the Detention of Foreign 'International terrorists" Alter-
natives/Special English Language Issue of Cultures \& Conflicts Vol 28 No 4 pp 491-515.

Hindess B 2008 'Government and Discipline' International Political Sociology Vol 2 No 3 pp 268-270.

Hyndman J 2010 'Introduction: the feminist politics of refugee migration' Gender, Place and Culture Vol 17 No 4 pp 453-459.

Joerges C 2006 'Deliberative Political Processes' Revisited: What Have We learned About the Legitimacy of Supranational Decision Making?' JCMS: Journal of Common Market Studies, Vol 44 No 4 pp 779-812.

Joly, D (ed.) 2002 Global Changes in Asylum Regimes, Macmillan Palgrave, Basingstoke.

Koslowski R \& D Kyle 2001 Global Human Smuggling John Hopkins University Press, Baltimore.

Löwenheim O 2007 "The Responsibility to Responsibilize: Foreign Offices and the Issuing of Travel Warnings « IPS Vol 1 No 3 pp 203-221.

Moravcsik, A 1993 'Preferences and Power in the European Community: A Liberal Intergovernmentalist Approach' Journal of Common Market Studies Vol 31 No 4 pp 473-524.

Moreno Lax 2008 Must EU Borders have Doors for Refugees? CRIDHO Working Paper 2008/03.

Neal A (2008) 'Goodbye War on Terror? Foucault and Butler on Discourses of Law, War and Exceptionalism' M. Dillon and A. Neal (eds) Foucault on Politics, Security and War Palgrave, Hounsmills pp 43-64.

Rijpma J 2010 FRONTEX: Successful Blame Shifting of the Member States? (ARI) Real Instituto Elcano, Madrid, Spain, 13 April.

Rose N 2008 Governing the Present Polity, Oxford.

Ruelle C 2005 'Population, milieu et normes - Note sur l' enracinement biologique de la biopolitique de Foucault' Labyrinthe 22 dossier : La biopolitique (d')après Michel Foucault pp 27-36.

Ryan B \& V. Mitsilegas 2010 (eds) Extraterritorial Immigration Control: Legal Challenges Martinus Nijhoff, Leiden.

Spijkerboer T 2000 Gender and Refugee Status Ashgate, Aldershot.

Tuitt, P 1996 False Images: Law's Construction of the Refugee, Pluto Press, Law and Social Theory Series, London.

Valverde M 2008 'Law versus History: Foucalt's Geneology of Modern Sovereignty' in M. Dillon and A Neal (eds) Foucault on Politics, Security and War Palgrave, Hounsmills pp 135-150.

Walker R.J.B. 1993 Inside/Outside: International Relations as International Theory CUP, Cambridge.

Walker R.J.B. 2009 After the Globe/Before the World Routledge, New York.

\section{Notes}

1 Geneva Convention relating to the Status of Refugees 189 UNTS 150, 28 Jul 1951 (entry into force: 22 Apr. 1954).

2 All references to the EU take into account the changes brought about in December 2009 by the entry into force of the Lisbon Treaty which creates two treaties - the Treaty on European Union (TEU) and the Treaty on the Functioning of the European Union (TFEU). A first draft of this paper was presented at Lund University, the Nordic Refugee Conference, February 2009. My sincere thanks to Professor Gregor Noll for inviting me to Lund and providing very valuable comments.

3 In particular the fall of the Berlin Wall is the signifier of the end of the Soviet Union style Communist regimes in Europe.

4 D. Joly (ed.) Global Changes in Asylum Regimes, Basingstoke: Macmillan Palgrave, 2002; P. Tuitt False Images: Law's Construction of the Refugee, (Pluto Press, Law and Social Theory Series), London, 1996. 
5 UNHCR Asylum Levels and Trends in Industrialized Countries 2009 UNHCR Geneva 23 March 2010; and its predecessors since 2000.

6 E. Guild, 'The Europeanisation of Europe's Asylum Policy' Int J Refugee Law (2006) 18: 630-651.

7 See G. Agamben Homo Sacer; Sovereign Power and Bare Life Stanford University Press, Stanford, 1998.

8 J. Caporaso, 'Integration Theory, Past and Future' in W Sandholtz and A Stone Sweet, European Integration and Supranational Governance OUP, Oxford, 1998; A Moravcsik, 'Preferences and Power in the European Community: A Liberal Intergovernmentalist Approach' Journal of Common Market Studies (1993) 31: 473-524, C Joerges 'Deliberative Political Processes' Revisited: What Have We learned About the Legitimacy of Supranational Decision Making?' JCMS: Journal of Common Market Studies, Vol 44 No 42006 pp 779-812.

9 R.J.B. Walker Inside/Outside: International Relations as International Theory CUP, Cambridge 1993.

10 M. Foucault, Discipline and Punish: the birth of the prison Penguin Books, London 1977 (translation: 1977 A. Sheridan); M. Foucault, Society must be defended: Lectures at the College de France 1975-76 Palgrave, New York 2003 (translation D. Macey 2003); M. Foucault, The Birth of Biopolitics: Lectures at the College de France 1978-1979 Palgrave, New York 2008 (translation G. Burchell 2008).

11 G. Agamben, Homo Sacer; M. Dillon and A. Neal Foucault on Politics, Security and War Palgrave, Hounsmills, 2008; T. Spijkerboer Gender and Refugee Status Ashgate, Aldershot, 2000.

12 E. Guild „Exceptionalism and Transnationalism: UK Judicial Control of the Detention of Foreign 'International terrorists' "Alternatives/Special English Language Issue of Cultures \& Conflicts Vol 28 No 4 August Oct 2003 pp 491-515.

13 B. Hindess 'Government and Discipline' International Political Sociology 2008, Vol 2 Issue 3 pp 268-270.

14 F. Gros États de violence: Essai sur la fin de la guerre Gallimard, Paris, 2006.

15 M. Foucault, Discipline and Punish: the birth of the prison Penguin Books, London 1977 (translation: 1977 A. Sheridan).

16 Depending on one's reading of Foucault's work over time from Societe, Territoire et Population (College de France lectures 1977-78) to 'The political technology of individuals' in L H Martin, H Gutman and P H Hutton (eds) Technologies of the Self: A Seminar with Michel Foucault Tavistock, London 1988. See also Mitchell Dean's explanation in Critical and Effective Histories: Foucault's Methods and Historical Sociology Routledge, New York, 1994, "It is germane - in light of the possible totalizing reading of the 'carceral' apparently authorised by the final part of Discipline and Punish (1977) that here the power of government attains pre-eminence over other forms such as not only sovereignty but also, rather intriguingly, discipline (1979a:20 [STP]« p 176. »However, central, it is perhaps time to say that this side retained an uncertain status in Foucault's thought. On the one hand, he did not bring the fragments on government together into a fuller, more explicit work at the time of his death, and we are left with a number of quite distinct, but nevertheless broad and coherent, formulations of this notion...Foucault's general characterisation of government as la conduite de la conduite or the conduct of conduct." $\mathrm{p} 178$.

17 D. Bigo 'Security: A Field Left Fallow' in M. Dillon and A. Neal Foucault on Politics, Security and War Palgrave, Hounsmills, 2008 pp 93-114.

18 N. Rose, Governing the Present Polity, Oxford, 2008 - in his introduction he develops Foucault's notion of governmentality as 'conduct of conduct'.

19 M. Dean Governmentality. 2nd Edition, Sage, London, 2009.
20 M. Foucault, Society must be defended: Lectures at the College de France 1975-76 Palgrave, New York 2003 (translation D. Macey 2003).

21 Though discipline is also related to the creation of knowledge as a form of power. As Bonditti points out, this makes discipline and biopolitics different from sovereignty.

22 M. Foucault, The Birth of Biopolitics: Lectures at the College de France 1978-1979 Palgrave, New York 2008 (translation G. Burchell 2008).

23 C. Ruelle 'Population, milieu et normes - Note sur l' enracinement biologique de la biopolitique de Foucault' Labyrinthe 22 (2005) dossier: La biopolitique (d')après Michel Foucault pp 27-36.

24 M. Valverde 'Law versus History: Foucalt's Geneology of Modern Sovereignty' M. Dillon and A Neal Foucault on Politics, Security and War Palgrave, Hounsmills, 2008 pp 135-150. Human rights norms here take their normal meaning of international and supranational human rights treaties.

25 A. Neal 'Goodbye War on Terror ? Foucault and Butler on Discourses of Law, War and Exceptionalism' M. Dillon and A. Neal Foucault on Politics, Security and War Palgrave, Hounsmills, 2008 pp 43-64.

26 R. B. J. Walker After the Globe/Before the World Routledge, New York, 2009.

27 UNHCR 2009: Global Trends http://www.unhcr.org/4c11f0be9. html (visited 18 August 2010).

28 European Commission Policy Plan on Asylum: An Integrated Approach to Protection Across the EU December 2008.

29 Council Directive 2004/83 on minimum standards on procedures in Member States for granting and withdrawing refugee status, adopted on 1 December 2005

30 M. Foucault, Discipline and Punish: the birth of the prison Penguin Books, London 1977 (translation: 1977 A. Sheridan) p 222.

31 M. Dean, Governmentality: Power and Rule in Modern Society Sage, London 1999 .

32 D. Bigo, 'Security: A Field Left Fallow' in Dillon, M \& Neal, A Foucault on Politics, Security and War Palgrave, Hounsmills, 2008 pp 93-114.

33 M. Foucault The Birth of Biopolitics: Lectures at the Collège de France 1978-1979 Palgrave, Houndsmill, 2008 (translation: G. Burchell).

34 O. Löwenheim "The Responsibility to Responsibilize: Foreign Offices and the Issuing of Travel Warnings" IPS (2007) Vol 1 No 3 pp 203-221.

35 M Dean, (1977) supra pp 222-223.

36 The EU's external border agency: Regulation 2007/2004 establishing External Borders Agency (OJ 2004 L 349/1).

37 D. Bigo, 'The Birth of Ban-opticon : Detention of Foreigners in (il)liberal Regimes' Paper presented at the annual meeting of the International Studies Association, Hilton Hawaiian Village, Honolulu, Hawaii, 5 March 2005.

38 For a collection of essays which develop this subject see: B. Ryan and V. Mitsilegas Extraterritorial Immigration Control: Legal Challenges Martinus Nijhoff, Leiden, 2010.

$39 \operatorname{COM}(2008) 68$ final.

40 The Returns Directive 2008/115 (OJ 2008 L 348/98) - deadline for transposition: 24 Dec. 2010)

$41 \mathrm{http} / /$ www.noborder.org/dead.php - No Borders is an NGO which keeps statistics of migrants who die seeking to enter the EU. Since December 2002 they have received information of 3,893 deaths (visited: 20 August 2010).

42 Human Rights Watch, Pushed Back, Pushed Around: Italy's Forced Return of Boat Migrants and Asylum Seekers and Libya's Mistreatment 
of Migrants and Asylum Seekers HRW, New York, 21 September 2009.

43 J. Rijpma FRONTEX: Successful Blame Shifting of the Member States? (ARI) Real Instituto Elcano, Madrid, Spain, 13 April 2010.

44 The ngo, Fortress Europe maintains a site with information about the deaths http://fortresseurope.blogspot.com/2006/02/immigrants-dead-at-frontiers-of-europe_16.html.

45 N. Rose Governing the Present Policy, London 2008.

46 An academic who has used Foucault's notion of conduct of conduct in relation to the treatment of asylum seekers and refugees is Jennifer Hyndman - for an overview see 'Introduction: the feminist politics of refugee migration' Gender, Place and Culture (2010) Vol 17 Issue 4 pp 453-459.

47 R. Koslowski \& D Kyle Global Human Smuggling John Hopkins University Press, Baltimore, 2001

48 A good example from the UK can be found in the judgment $R v S e c$ retary of State ex parte European Roma Rights Centre [2004] UKHL 55. Also see Moreno Lax Must EU Borders have Doors for Refugees? CRIDHO Working Paper 2008/03.

49 According to UNHCR in 2005 the EU 27 states entertained 240,950 asylum applications; in 2006 the number was 201,000; in 2007 it was 223,670, the next year 239,150 and in 2009 it reached 246,210. Asylum Levels and Trends in Industrialized Countries 2009 UNHCR, Geneva, 23 March 2010. The population of the EU 27 is over 500 million.

50 Of course asylum seekers can claim the benefit of Article 8 ECHR which the ECtHR interpreted as incompatible with police stop and search powers which are not based on reasonable suspicion of criminal activity Gillan \& Quinton v UK ECtHR 28 June 2010 Application no. 4158/05. However, the fear of being refused asylum acts as a disciplining technique which means asylum seekers very rarely complain about human rights abuses other than in relation to the substance of their claims at least during the procedure.

51 Council of Europe, Commissioner for Human Rights "It is wrong to criminalize migration" August 2008.

52 Directive 2003/86 on family reunification (OJ 2003 L 251/12): transposition deadline 3 October 2005.

53 The Commission's proposal for a Recast of the Qualification Directive proposes the upward harmonization of the rights of beneficiaries of subsidiary protection to those of refugees though it is far from clear that this will be accepted by the Council: COM (2009) 551.

54 As the exercise of the power to designate a country as a European safe third country was challenged by the European Parliament be- fore the European Court of Justice which handed down judgment in favour of the Parliament in May 2008, there has not yet been the necessary Council Decision C-133/06 Parliament v Council 6 May 2008.

55 UNHCR Asylum Levels and Trends in Industrialized Countries 2009UNHCR, Geneva, 23 March 2010.

56 http://www.unhcr.org/statistics.html

57 The Commission's proposal for a recast of the Procedures Directive published in $2009(\operatorname{COM}(2009) 554)$ recommends the abolition of the category of European safe third countries but it is unclear whether the Council will accept this.

58 For instance the UK statistics use in the title »removals of failed applicants... The numbers of so called failed asylum seekers removed from the UK varied from 6,800 in 2003 to 3035 in 2007; Asylum Statistics United Kingdom 2007, 21 August 2008.

59 M. Foucault The Birth of Biopolitics: Lectures at the College de France 1978-1979 Palgrave, Houndsmill, 2008 (translation: G. Burchell) - see also footnote 17; G Burchell 'Liberal Government and Techniques of the Self' in A Barry, T Osborne and N Rose Foucault and Political Reason, Liberalism, Neo-Liberalism and Rationalities of Government University of Chicago Press, Chicago, 1996 p 44.

60 See footnote 5 .

$61 \mathrm{~J}$. Butler Gender Trouble Feminism and the Subversion of Identity Routledge, New York, 1999.

62 An important discussion also needs to take place on the identity of the target population as regards the management of life - is it the population of asylum seekers or the EU population which must be protected from asylum seekers?

63 see for instance Judith Kumin, Director, UNHCR Bureau for Europe, to the Cross-Dimensional Corfu Meeting, Organization for Security and Co-operation in Europe (OSCE), Vienna, 28 May 2010 at http://www.unhcr.org/4c03cf106.html (visited 20 August 2010).

64 Article 25(2)(c) Procedures Directive.

65 Salah Sheekh $v$ Netherlands ECtHR 11 January 2007, Application no. 1948/04.

66 For a good example see UNHCR on the Procedures Directive: C. Costello, The European Asylum Procedures Directive in Legal Contest UNHCR Research Paper 134, November 2006.

$67 \operatorname{COM}(2009) 554$. 